\title{
Cystic parathyroid glands in MEN1: A rare entity?
}

\author{
Tiziana Cavalli ${ }^{1} \cdot$ Francesco Giudici $^{1} \cdot$ Gabriella Nesi $^{1} \cdot$ Andrea Amorosi $^{2}$ • \\ Raffaella Santi ${ }^{1}$ - Maria Luisa Brandi ${ }^{1}$ - Francesco Tonelli ${ }^{1}$
}

\begin{abstract}
Approximately 300 cases of sporadic parathyroid cyst (PCs) have been reported to date. Only two cases have been described in MEN1 so far. Detection by imaging could be challenging, especially in multiglandular primary hyperparathyroidism (HPT) and clinical outcome could be different. During the period 1990-2014, 71 MEN1 patients were operated for primary hyperparathyroidism in our centre. We report three cases of PCs in MEN1 patients affected by HPT, who underwent a total or subtotal parathyroidectomy with transcervical thymectomy. In our series, all three patients had an unsatisfactory postoperative course, at variance with the high percentage (over $90 \%$ ) of long-term success in MEN1 patients operated at our centre. One patient affected by cystic degeneration of all the four parathyroid glands reported persistent hypoparathyroidism, despite autografts of parathyroid tissue. For the other two cases, surgery failed to cure hyperparathyroidism, perhaps because of the presence of undetected ectopic parathyroid tissue. In the context of a multiglandular disease such as MEN1 syndrome, PCs seem rare but our experience shows about a $4 \%$ incidence. Furthermore their presence, even in expert hands, could affect the preoperative identification of the parathyroid glands due to the difficult differential diagnosis between PC and other cystic lesions of the neck, and intraoperative detection of the glands as well as the postoperative outcome.
\end{abstract}

Tiziana Cavalli

tiziana.cavalli@gmail.com

1 Department of Surgery and Translational Medicine, University of Florence, Largo Brambilla 3, 50134 Florence, Italy

2 Institute of Pathology, Department of Health Sciences, University "Magna Graecia" of Catanzaro, Catanzaro, Italy
Keywords MEN1 · HPT · Parathyroid cysts · Surgery · PTH

$\begin{array}{ll}\text { Abbreviations } \\ \text { PC } & \text { Parathyroid cyst } \\ \text { MEN1 } & \text { Multiple endocrine neoplasia syndrome type 1 } \\ \text { HPT } & \text { Hyperparathyroidism } \\ \text { PTH } & \text { Parathyroid hormone } \\ \text { IOPTH } & \text { Intraoperative parathyroid hormone } \\ \text { US } & \text { Ultrasonography } \\ \text { FNA } & \text { Fine needle aspiration } \\ \text { MRI } & \text { Magnetic resonance imaging } \\ \text { SPECT- } & \text { Single-photon emission computed } \\ \text { CT } & \text { tomography/computed tomography } \\ \text { VIP } & \text { Vasoactive intestinal peptide } \\ \text { HPT-JT } & \text { Hyperparathyroidism-jaw tumour syndrome }\end{array}$

\section{Introduction}

Parathyroid cysts (PCs) were originally described in 1880 by the Swedish anatomist Sandstrom [1], and removed for the first time by a Belgian surgeon, Goris, in 1905 [2]. Crile Jr. and Perryman [3] were the first to diagnose PCs using fine needle aspiration (FNA) in 1953.

PCs are rare lesions, often discovered incidentally during neck surgery or imaging procedures. To date, $<300$ cases of PCs have been documented, accounting for $0.08-3.41 \%$ of all parathyroid lesions [4-6]. McCoy et al. [7] found cystic parathyroid lesions in $3 \%$ of 1769 patients undergoing surgery for primary hyperparathyroidism (HPT). In a retrospective study of 6621 patients submitted to a neck ultrasonography (US), Cappelli et al. [8] reported an incidence of $0.075 \%$ in an unselected group. PCs are more common in the fourth and fifth decades of life [9-11]; 
however, several paediatric cases have also been described [12]. PCs may be functioning or non-functioning. Nonfunctioning cysts encompass $90 \%$ of cases and occur more commonly in females [13, 14]. Functioning cysts usually affect males and are associated with primary HPT [13].

Clinical presentation of PCs depend on site, size, and hormonal activity. Although most PCs are orthotopic, ectopic localization is possible in the cervical region, including both the thyroid and thymus [15-18]. Mediastinal PCs are usually large $(\geq 4 \mathrm{~cm})$, causing compressive symptoms such as dysphagia and dyspnea [13, 19, 20], at times mimicking retrosternal goitre [14]. Vocal cord paralysis due to compression on the recurrent laryngeal nerve [21-23], respiratory failure and jugular or innominate vein thrombosis have also been reported as complications [24]. Haemorrhage is an additional complication, which causes a rapid increase in volume and adhesion to surrounding structures, thus suggesting malignancy.

Only two cases of PC have been described in MEN1, both occurring in Japanese patients $[25,26]$. We report three cases of PC in MEN1 patients, from different families, who underwent surgery at our centre (Table 1).

\section{Patients and methods}

During the period 1990-2014, 71 MEN1 patients were operated for primary HPT in our Centre. We report three cases of PCs in MEN1 patients affected by HPT, who underwent a total or subtotal parathyroidectomy with transcervical thymectomy. Histology confirmed the presence of PC in all patients (Fig. 1). Written informed consent was obtained from all the study participants, obtaining ethical approval from the local Experts Committee of Careggi Hospital.

\section{Case 1}

A 46-year-old man was diagnosed with primary HPT in MEN1 syndrome (gene mutation: c.1522C $>\mathrm{T}$ exon 10).
Neck US did not detect any parathyroid lesion, while MIBI scintigraphy revealed an increased uptake at the left lower pole of the thyroid. The patient initially refused surgery but, due to his high serum calcium levels, was given the calcimimetic agent cinacalcet. Three months later, he underwent total parathyroidectomy and thymectomy with intraoperative parathyroid hormone (IOPTH) monitoring. After mobilization of the thyroid lobes, posterior to the right inferior thyroid artery, an upper parathyroid gland $(30 \times 19 \times 16 \mathrm{~mm})$ of cystic appearance was found. The right lower gland, located within the thyroid capsule, appeared normal $(5 \times 3 \times 2 \mathrm{~mm})$ and was left in place until the end of surgery to preserve its vascularisation for subsequent autotransplantation. On the left side, the upper parathyroid gland measured $23 \times 11 \times 8 \mathrm{~mm}$ and the lower gland $9 \times 6 \times 5 \mathrm{~mm}$. The thymus and thyro-thymic ligament were then removed en-bloc. Ten minutes after clamping the right lower parathyroid gland, PTH levels progressively dropped, falling to values at the limits of measurability (Fig. 2). Ten submillimetric fragments from this gland were grafted in the non-dominant forearm and several tissue fragments were also cryopreserved. Histology showed chief cell hyperplasia in the four parathyroid glands, all cystic in appearance. The parathyroid tissue diffusely stained for parafibromin.

In the postoperative course, hypoparathyroidism occurred, requiring calcium and vitamin D supplements.

After 3 months, the patient was subjected to a spleenpreserving distal pancreatectomy and cholecystectomy. Pathological examination revealed endocrine multihormonal microadenomatosis of the pancreas. There was no evidence of lymph node metastasis.

Eight months after neck surgery, persistent hypocalcemia required autotransplantation of the cryopreserved parathyroid tissue and approximately 30 fragments were inserted into the fibres of the brachioradialis muscle. However, calcium and PTH levels did not normalize and the patient is currently taking calcium and calcitriol tablets.

Table 1 Clinico-pathological features of MEN1 associated PC

\begin{tabular}{|c|c|c|c|c|c|c|}
\hline Case & US & Scintigraphy/MRI & $\begin{array}{l}\text { No. glands } \\
\text { detected } \\
\text { at surgery }\end{array}$ & $\begin{array}{l}\text { No. cystic } \\
\text { glands }\end{array}$ & $\begin{array}{l}\text { Preoperative } \\
\text { therapy (Cinacalcet) } \\
\text { (months) }\end{array}$ & Outcome \\
\hline $1(\hat{\jmath}, 46)$ & 0 & 1 & 4 & 4 & 1 & Hypoparathyroidism \\
\hline $2(+, 30)$ & $\begin{array}{l}2 \\
\text { Polylobulated, calcific }\end{array}$ & $\begin{array}{l}0 \\
\text { MRI negative for } \\
\text { neck or mediastinal } \\
\text { lesions }\end{array}$ & 3 & 1 & 8 & Hyperparathyroidism \\
\hline $3(\hat{0}, 62)$ & $\begin{array}{l}3(+1 ?) \\
\text { Rich vascularization }\end{array}$ & 2 & 4 & 1 & 25 & $\begin{array}{l}\text { Normal calcemia, mild } \\
\text { elevation of PTH }\end{array}$ \\
\hline
\end{tabular}



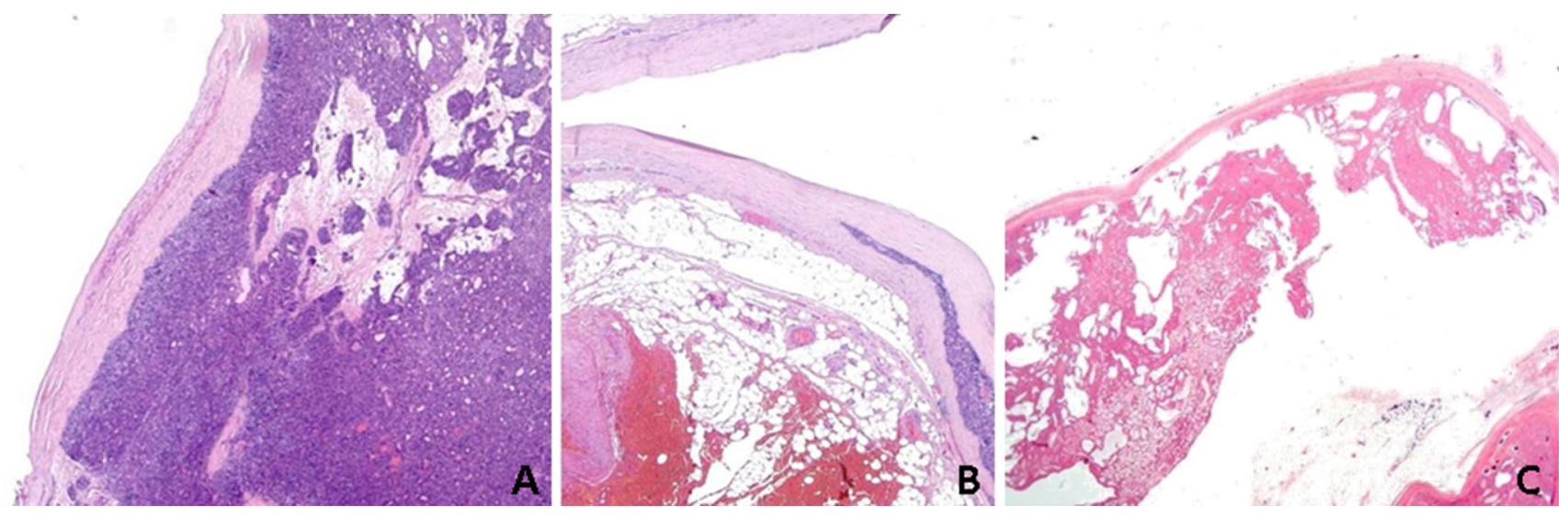

Fig. 1 Histology was consistent with PC (H\&E, original magnification, $\times 10)$ for all patients $(\mathbf{a}=$ case $1, \mathbf{b}=$ case 2 , $\mathbf{c}=$ case 3 )

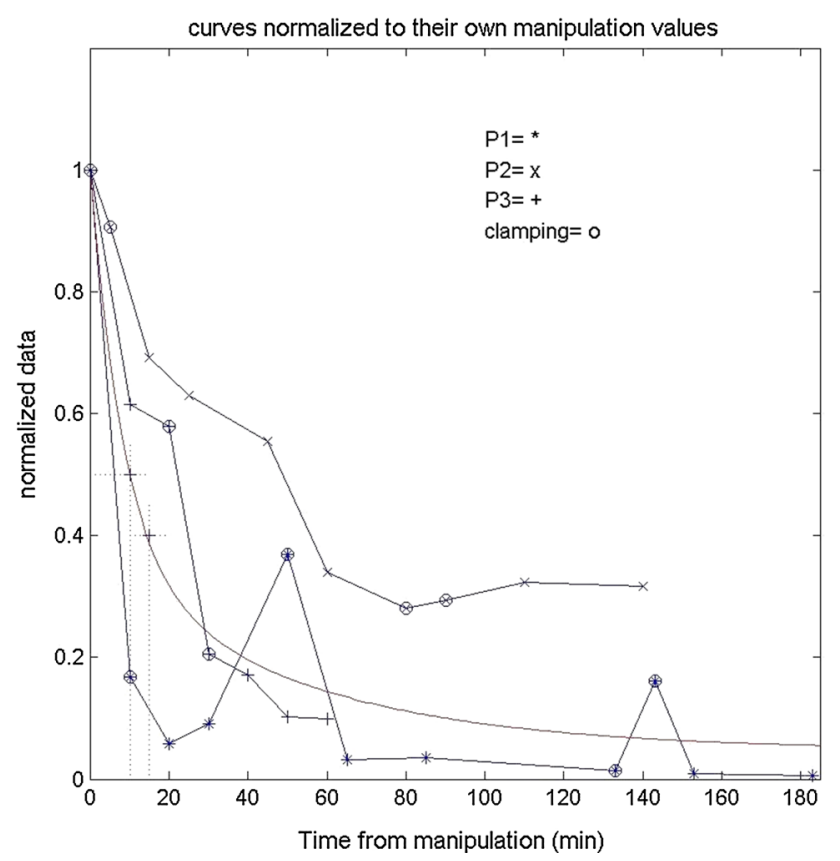

Fig. 2 IOPTH decay curves from first gland "manipulation". At the end of procedure, PTH was almost unmeasurable in patient 1 (P1), while in P2 and P3, PTH dropped variably below "manipulation" value without reaching unmeasurable values. Continuous curve represents the bi-exponential PTH decay curve typical of sporadic primary HPT

\section{Case 2}

HPT was diagnosed in a 30-year-old woman affected with MEN1 syndrome (gene mutation: frameshift 613delT, exon 3). Frequent hypoglycaemic crises due to pancreatic insulinoma required prompt surgical treatment and she received cinacalcet for 8 months to control her hypercalcemia before undergoing parathyroidectomy. Neck US demonstrated a small, slightly hypoechoic nodule with smooth contours, measuring $4 \times 3 \times 2 \mathrm{~mm}$, in the left thyroid lobe. A hypoechoic polycystic lesion, measuring
$7 \times 6 \times 15 \mathrm{~mm}$ and exhibiting small calcifications, was identified caudal to the right thyroid lobe. Two anechoic nodules of 6 and $5 \mathrm{~mm}$ were also seen below the left thyroid lobe. On a subsequent thyroid US, two formations compatible with parathyroid glands were found at the upper pole of the right lobe and at the lower pole of the left lobe, 11.8 and $4.6 \mathrm{~mm}$ respectively.

After 8 months of medical therapy, the patient underwent bilateral neck exploration and thymectomy. At surgery, both the upper glands were increased in volume: the left one measured $25 \times 10 \times 5 \mathrm{~mm}$; the right one, $15 \times 9 \times 5 \mathrm{~mm}$, sited at the dihedral angle between the inferior thyroid artery and the laryngeal nerve, was adherent to the ipsilateral recurrent nerve. A 5-mm nodule, attached to the inferior right thyroid pole, was detected and removed. One hour after the final parathyroidectomy, PTH was half the manipulation value although it did not reach undetectable levels (Fig. 2). No further glands were found. Histology revealed chief cell hyperplasia in the three orthotopic glands removed, whereas the 5-mm nodule attached to the right lower thyroid pole was diagnosed as a cystic parathyroid gland. Immunostain for parafibromin resulted positive.

Persistent HPT after surgery required treatment with cinacalcet (Table 2).

\section{Case 3}

A 62-year-old man, operated for a pancreatic VIPoma metastatic to the liver, was diagnosed with MEN1 syndrome (gene mutation: frameshift 67ins5 bp, exon 2). He received cinacalcet for 25 months for severe HPT before undergoing total parathyroidectomy and thymectomy. Preoperative neck magnetic resonance imaging (MRI) without contrast medium revealed a $3.5 \mathrm{~mm}$ subfascial lipoma in the posterior aspect of the cervical spine. A hybrid single-photon emission computed tomography/computed tomography (SPECT-CT) showed enhanced 
Table 2 Patient preoperative and postoperative PTH and calcium values

\begin{tabular}{|c|c|c|c|}
\hline Biochemical analysis & \begin{tabular}{l} 
Patient 1 \\
\multirow{\jmath}{*}{, 46}
\end{tabular} & $\begin{array}{l}\text { Patient } 2 \\
\text { o, } 30\end{array}$ & $\begin{array}{l}\text { Patient } 3 \\
\widehat{\jmath}, 62\end{array}$ \\
\hline \multicolumn{4}{|c|}{ Calcemia (mg/dL) (n.r. $=8.2-10.7)$} \\
\hline Preop & $11.7\left(11.8\right.$ pre- $\left.C^{\mathrm{a}}\right)$ & $10.0\left(11.3\right.$ pre- $\left.C^{a}\right)$ & $10.6\left(11.4\right.$ pre- $\left.C^{\mathrm{a}}\right)$ \\
\hline Postop & 7.9 & 10.2 & 9.0 \\
\hline \multicolumn{4}{|c|}{ Ionized calcium $(\mathrm{mg} / \mathrm{dL})(\mathrm{n} . \mathrm{r} .=4.3-5.3)$} \\
\hline Preop & 5.6 & 5.2 & 5.4 \\
\hline Postop & 4.1 & 5.4 & 4.5 \\
\hline \multicolumn{4}{|c|}{ PTH (pmol/L) (n.r. = 1.3-7.6) } \\
\hline Preop & 11.9 & 9.0 & 55.6 \\
\hline Postop & 1.1 & 9.5 & 9.0 \\
\hline
\end{tabular}

n.r. normal range

a pre- $\mathrm{C}=$ before starting Cinacalcet

signals both in the mid third of the left thyroid lobe and below the lower pole.

Bilateral neck exploration demonstrated a cystic right upper parathyroid gland $(39 \times 25 \times 20 \mathrm{~mm})$, adherent to the homolateral thyroid lobe, which was then removed. Close to the left upper pole two "kissing" parathyroid glands measuring $23 \times 19 \times 12 \mathrm{~mm}$ and $24 \times 10 \times 6 \mathrm{~mm}$ were excised. After the removal of the left lower gland $(13 \times 12 \times$ $10 \mathrm{~mm}$ ) sited below the thyroid lower pole, PTH dropped to normal but did not reach unmeasurable values (Fig. 2). Consequently, a portion of the left inferior parathyroid was cryopreserved but no autograft was performed. No further parathyroid glands were found on cervical exploration.

Histology revealed nodular chief cell hyperplasia with dystrophic calcifications in the large cystic gland. Parafibromin was strongly expressed and the proliferation index (Ki-67) was $<1 \%$ (Fig. 3). The remaining three glands showed diffuse chief cell hyperplasia. On follow-up, the patient was normocalcemic, but PTH levels started to rise 3 months after surgery.

\section{Discussion}

We present three new cases of PC in MEN1 patients highlighting their clinical heterogeneous clinical manifestations. Only two cases of PC in MEN1 have been previously described. In the report by Tamiya et al. [25] a large cystic lesion $(6500 \mathrm{mg})$ in the context of multinodular goiter was histologically diagnosed as a PC, while the other three parathyroid glands were found to be hyperplastic; all laboratory data returned to normal after parathyroidectomy. The other case by Kinoshita et al. [26] concerns a MEN1 patient affected by pituitary adenoma, Zollinger-Ellison syndrome and HPT with a large PC, but clinical information is available only in Japanese.
Interestingly, analyzing our data about parathyroid surgery in 71 MEN1 patients, we can estimate an incidence of $4.2 \%$ of patients affected by PC.

PC pathogenesis is still unclear. Non-functiong PCs may originate as remnants of the third or fourth branchial cleft [10]. Histologically, the wall of these cysts often contains fragments of salivary, adipose or thymic tissue, providing further evidence for this hypothesis. Alternatively, they may derive from the coalescence of microcysts [10]. Recent studies suggest that functioning PCs may represent cystic degeneration of a pre-existing parathyroid adenoma or, rarely, a carcinoma [27-29]. In HPT-jaw tumour syndrome (HPT-JT), patients generally present one or two parathyroid adenomas, often with cystic features, and bear a significantly increased risk of parathyroid carcinoma. Inactivating germ-line HRPT2 (OMIM 145001, region 1q25) mutations have been reported in kindred with HPT-JT, as well as in familial isolated primary HPT [30-36]. The HRPT2 gene is expressed in several human tissues including parathyroid, bone and kidney [31]. It encodes parafibromin, a 531-amino acid protein belonging to human Paf1 complex, involved in cell proliferation, transcription regulation and histone modification with tumour-suppressor properties [37, 38]. The majority of sporadic parathyroid carcinomas harbour germ-line and/or somatic-type HRPT2 mutations, with loss of parafibromin immunoreactivity [33, 35, 39, 40]. While somatic MEN1 mutations are common even in sporadic parathyroid adenomas, somatic HRPT2 mutations have only been reported in four out of the 137 adenomas studied to date, all with cystic features [31, 33, 35, 41]. These findings suggest that HRPT2 may participate in the pathogenesis of parathyroid carcinoma [42], but also of benign parathyroid tumours with cystic changes. However, in our three cases of PC in MEN1, parafibromin was normally expressed. 

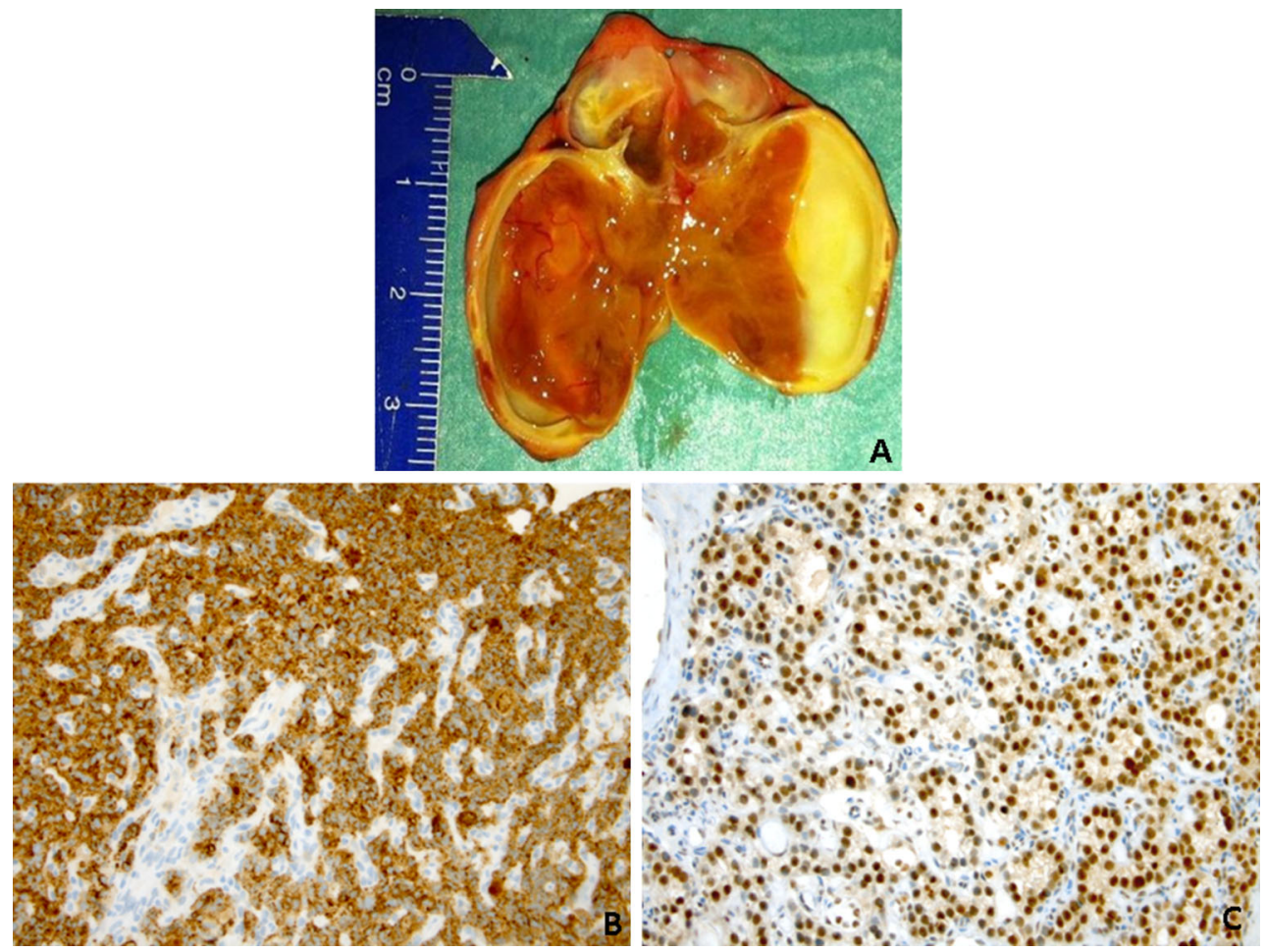

Fig. 3 a Large PC with thickened fibrous wall. b The parathyroid tissue was intensely reactive for parathyroid hormone. c Nuclear parafibromin staining was retained (original magnifications, $\times 400$ )

Radiological diagnosis of PCs can be challenging. Neck US is a valuable tool to distinguish PCs from thyroid or other cystic masses such as thymic, thyreoglossal duct, branchial cleft cysts or lymphangioma [43, 44]. However, in our series, neck US did not show an high sensitivity for PC: for example in the first case, even in the presence of two large glands (about $2.5 \mathrm{~cm}$ in diameter) the radiologist was not able to assess the parathyroideal nature of the cystic lesions. Radio-nucleotide scans usually reveal areas with decreased or no uptake, thus mimicking cold nodules. Technetium-99 m sestamibi imaging may furnish equivocal results, even in functioning PCs [45]. CT and MRI findings are nonspecific, and PCs may be difficult to differentiate from other cystic lesions located in the lower neck or in the superior mediastinum. However, a PC should be considered when radiological images demonstrate a cystic lesion posterior to the thyroid, with an extension to the superior mediastinum [46].

FNA is a valid diagnostic tool. Watery, colourless crystal clear fluid suggests non-functioning PC, although a coloured aspirate does not exclude this entity [47]. Functioning PCs may hold a yellow or brown aspirate as a result of degeneration of a parathyroid adenoma containing hemosiderin. Diagnosis can be established by elevated PTH levels in the aspiration fluid [48]. PTH concentration in the cystic fluid of non-functioning PCs ranges from several hundred to over $400,000 \mathrm{pg} / \mathrm{ml}$ with normal serum
PTH levels [49]. Thyroid cysts usually yield a yellowish or bloody aspirate with high thyroglobulin and undetectable PTH levels,whereas a yellowish and viscous aspirate is characteristic of branchial cysts [50].

Grossly, PCs may measure up to $10 \mathrm{~cm}$ in diameter and are almost always unilocular. On microscopic examination, nonfunctioning PCs exhibit a smooth inner surface wall with an epithelial lining consisting of a single layer of cuboidal or columnar cells staining positive for glycogen [51].

Taking into account the size of the cyst, standard treatment of uncomplicated non-functioning PCs is percutaneous aspiration, first described by Clark [29]. Surgical excision is the gold standard for functioning PC and nonfunctioning $\mathrm{PC}$ with compressive symptoms [52].

IOPTH monitoring could be useful to assess surgical outcome, but in PC it can be misleading if the cyst is ruptured and in MEN1 cases it can provide false positive results: in our case 1, after removal of the first parathyroid gland, the PTH decay followed the bi-exponential curve typical of sporadic primary HPT (continuous curve in Fig. 2) as we described in a previous paper [53]. Therefore, in MEN1 we believe that IOPTH is useful only to assess the absence of residual parathyroid tissue after total parathyroidectomy, revealing extremely low, almost unmeasurable serum PTH values.

Calcium levels should be checked postoperatively since hypocalcemia has been reported after successful removal 
of predominantly larger hyperfunctioning cysts (especially lesions weighing 4 grams or more; $p=0.03$ ) [7].

In our series, all three patients received cinacalcet before parathyroidectomy $(60 \mathrm{mg}$ daily). The postoperative course was unsatisfactory in all cases (Table 1), at variance with the high percentage (over $90 \%$ ) of recurrence-free rate at more than 10 years follow-up in MEN1 patients operated at our centre.

Cinacalcet hydrochloride has been approved for the treatment of hypercalcemia in patients with parathyroid carcinoma and in primary HPT patients unable to undergo surgery [54]. Three separate studies have reported its effectiveness in 11 MEN1 patients [54-56]. Cinacalcet is also the only available potent calcimimetic for the management of secondary HPT [57]. No obvious adverse effects of calcimimetic agents have been noted in patients undergoing parathyroidectomy for HPT.

During neck surgery for parathyroid hyperplasia, cystic degeneration can modify gland architecture or mimic fusion of two glands, leading to a higher risk of undertreatment. In our series, surgical failure suggests that parathyroid adenomas with cystic degeneration may exhibit a moderate endocrine activity compared with usual hyperplastic or adenomatous glands. Their behaviour resembles that of a normal parathyroid gland, possibly suppressed by the hormone produced by other adenomas, as in patient 2 , who had a small supernumerary intrathyroid cystic gland.

Patient 1, who had four cystic hyperplastic glands, presented postoperative hypoparathyroidism after the failure of parathyroid tissue grafts, in spite of the attention that the surgical team paid to avoid pre-graft gland ischaemia, which lasted about $15 \mathrm{~min}$. The subsequent graft of further frozen parathyroid tissue was not efficacious to provide a correct calcemia. Patient 3, who was affected by parathyroid hyperplasia with an intrathyroid cystic gland, and showed mildly elevated PTH levels at 3 months' follow up, might have had a fifth gland, which neither instrumental examination nor surgical exploration discovered after the removal of the other glands.

In recurrent cases, the injection of sclerosing agents (e.g. tetracycline solution, ethanol) into the cyst entails the risk of fibrosis and recurrent laryngeal nerve palsy, especially when the inferior parathyroid is involved $[58,59]$.

\section{Conclusions}

PCs are uncommon findings in clinical practice. The vast majority are non-functioning and asymptomatic. Their identification can be challenging as they can be confused with thyroid lesions. FNA is useful for diagnosis and initial treatment of non-functioning cysts. Surgical excision is recommended in the case of HPT, or when relapse and compressive symptoms occur. In the context of a multiglandular disease such as MEN1 syndrome, PCs seem rare but our experience shows about a $4 \%$ incidence. Furthermore their presence, even in expert hands, could affect pre- and intraoperative detection of the glands as well as the postoperative outcome.

Acknowledgments The authors are grateful to Professor Fabrizio Locchi (Physics, University of Florence) for having created the graph on the intraoperative PTH monitoring.

Author contributions Tiziana Cavalli, Francesco Giudici, and Francesco Tonelli: substantial contributions to conception and design, acquisition of data, analysis and interpretation of data; drafting the article and revising it critically for important intellectual content; final approval of the version to be published, and agreement to be accountable for all aspects of the work in ensuring that questions related to the accuracy or integrity of any part of the work are appropriately investigated and resolved. Gabriella Nesi, Andrea Amorosi, Raffaella Santi: acquisition of data, drafting the work, revising it critically for important intellectual content, final approval of the version to be published, and agreement to be accountable for all aspects of the work in ensuring that questions related to the accuracy or integrity of any part of the work are appropriately investigated and resolved. Maria Luisa Brandi: Substantial contributions to the conception and design of the work, the analysis and interpretation of data for the work, drafting the work, revising it critically for important intellectual content.

\section{Compliance with ethical standards}

Conflict of interest The authors certify that there is no present or potential conflict of interest in relation to this article and furthermore state there are no financial interests or connections, direct or indirect, or other situations that might raise the question of bias in the work reported or the conclusions, implications, or opinions stated-including pertinent commercial or other sources of funding for the individual author(s) or associated department(s) or organization(s), personal relationships, or direct academic competition.

\section{References}

1. Sandstrom I (1880) Om en kortel hos mennishkan och atskilliga doggdjus. Ups Lakafor Forhandl 14:441-471

2. Goris D (1905) Extirpation de trios lobules parathyroidens kystiques. Ann Soc Belge Chir 5:394-400

3. Crile G Jr, Perryman RG (1953) Parathyroid cysts; report of five cases. Surgery 34:151-154

4. Rojdmark JS, Mouchik JM (1998) Concentrations of parathyroid hormone in functioning and non-functioning parathyroid cysts. Eur J Surg 164:65-67

5. Pinney SP, Daly PA (1999) Parathyroid cyst: an uncommon cause of a palpable neck mass and hypercalcemia. West $\mathrm{J}$ Med 170:118-120

6. Wani S, Hao Z (2005) Atypical cystic adenoma of the parathyroid gland: case report and review of literature. Endocr Pract 11:389-393

7. McCoy KL, Yim JH, Zuckerbraun BS, Ogilvie JB, Peel RL et al (2009) Cystic parathyroid lesions: functional and nonfunctional parathyroid cysts. Arch Surg 144:52-56 
8. Cappelli C, Rotondi M, Pirola I, De Martino E, Leporati P et al (2009) Prevalence of parathyroid cysts by neck ultrasound scan in unselected patients. J Endocrinol Invest 32:357-359

9. Wirowski D, Wicke C, Böhner H, Lammers BJ, Pohl P et al (2008) Presentation of 6 cases with parathyroid cysts and discussion of the literature. Exp Clin Endocrinol Diabetes 116:501-506

10. Ippolito G, Palazzo FF, Sebag F, Sierra M, De Micco C et al (2006) A single-institution 25-year review of true parathyroid cysts. Langenbecks Arch Surg 391:13-18

11. Lydiatt DD, Byers RM, Khouri KG, Whitworth PW, Sellin RV (1993) Functional parathyroid cyst and hypocalciuric hypercalcemia. Ear Nose Throat J 72:142-144

12. Entwistle JW, Pierce CV, Johnson DE, O'Donovan SC, Bagwell CE et al (1994) Parathyroid cysts: report of the sixth and youngest pediatric case. J Pediatr Surg 29:1528-1529

13. Umemori Y, Makihara S, Kotani K, Washio K (2002) Mediastinal parathyroid cyst with tracheal constriction. Jpn J Thorac Cardiovasc Surg 50:85-87

14. McKay GD, Ng TH, Morgan GJ, Chen RC (2007) Giant functioning parathyroid cyst presenting as a retrosternal goiter. ANZ J Surg 77:297-304

15. Halenka M, Frysak Z, Koranda P, Kucerova L (2008) Cystic parathyroid adenoma within a multinodular goiter: a rare cause of primary hyperparathyroidism. J Clin Ultrasound 36:243-246

16. Rickels MR, Langer JE, Mandel SJ (2004) Hyperfunctioning intrathyroidal parathyroid cyst. J Clin Endocrinol Metab 89:1051-1052

17. Mitmaker B, Lerman S, Lamoureux E, Begin L (1991) Parathyroid cyst: diagnosis and treatment of an unusual surgical problem. Can J Surg 34:59-61

18. McCluggage WG, Russell CF, Toner PG (1995) Parathyroid cyst of the thymus. Thorax 50:913-914

19. Shields TW, Immerman SC (1999) Mediastinal parathyroid cysts revisited. Ann Thorac Surg 67:581-590

20. Gamondes JP, Maret G, Berger G, Brune J, Joud R (1978) Parathyroid adenoma of the upper mediastinum with blood-filled cyst causing dyspnoea. Nouv Presse Med 7:41-49

21. Sen P, Flower N, Papesch M, Davis A, Spedding AV (2000) A benign parathyroid cyst presenting with hoarse voice. J Laryngol Otol 114:147-148

22. Grey AB, Shaw JH, Anderson NE, Holdaway IM (1993) Parathyroid cyst with recurrent vocal cord paresis. Aust N Z J Surg 63:561-562

23. Coelho DH, Boey HP (2006) Bening parathyroid cyst causing vocal fold paralysis: a case report and review of the literature. Head Neck 28:564-566

24. Gattas N, Solt I, Loberant N, Hazani E, Rimon D (2007) Parathyroid cyst associated with acute respiratory failure and jugular vein thrombosis. Harefuah 146:599-601

25. Tamiya H, Miyakawa M, Suzuki H, Takesita A, Ohashi K et al (2013) A large functioning parathyroid cyst in a patient with multiple endocrine neoplasia type 1. Endocr J 60:709-714

26. Kinoshita Y, Nonaka H, Yamaguchi H, Ichikawa M, Suzuki S et al (1986) A case of multiple endocrine neoplasia type 1 with growth hormone and prolactin secreting pituitary adenoma, functioning large parathyroid cyst, and Zollinger-Ellison syndrome. Nihon Naika Gakkai Zasshi 75:512-521 (in Japanese)

27. Makino T, Sugimoto T, Kaji H, Yamaguchi T, Kitazawa R et al (2003) Functioning giant parathyroid cyst with high concentration of CA 19-9 in cystic fluid. Endocr J 50:215-219

28. Fallon MD, Haines JW, Teitelbaum SL (1982) Cystic parathyroid gland hyperplasia-hyperparathyroidism presenting as a neck mass. Am J Clin Pathol 77:104-107

29. Clark OH (1978) Parathyroid cysts. Am J Surg 135:395-402
30. Carpten JD, Robbins CM, Villablanca A, Forsberg L, Presciuttini $S$ et al (2002) HRPT2, encoding parafibromin, is mutated in hyperparathyroidism-jaw tumor syndrome. Nat Genet 32:676-680

31. Villabianca A, Calender A, Forsberg L, Höög A, Cheng JD et al (2004) Germline and de novo mutations in the HRPT2 tumour suppressor gene in familial isolated hyperparathyroidism (FIHP). J Med Genet 41:e32

32. Howell VM, Haven CJ, Kahnoski K, Khoo SK, Petillo D et al (2003) HRPT2 mutations are associated with malignancy in sporadic parathyroid tumours. J Med Genet 40:657-663

33. SimondsWF Robbins CM, Agarwal SK, Hendy GN, Carpten JD et al (2004) Familial isolated hyperparathyroidism is rarely caused by germline mutation in HRPT2, the gene for the hyperparathyroidism-jaw tumor syndrome. J Clin Endocrinol Metab 89:96-102

34. Cavaco BM, Guerra L, Bradley KJ, Carvalho D, Harding B et al (2004) Hyperparathyroidism-jaw tumor syndrome in Roma families from Portugal is due to a founder mutation of the HRPT2 gene. J Clin Endocrinol Metab 89:1747-1752

35. Cetani F, Pardi E, Borsari S, Viacava P, Dipollina G et al (2004) Genetic analyses of the HRPT2 gene in primary hyperparathyroidism: germline and somatic mutations in familial and sporadic parathyroid tumors. J Clin Endocrinol Metab 89:5583-5591

36. Moon SD, Park JH, Kim EM, Kim JH, Han JH et al (2005) A Novel IVS2-1G $>$ A mutation causes aberrant splicing of the HRPT2 gene in a family with hyperparathyroidism-jaw tumor syndrome. J Clin Endocrinol Metab 90:878-883

37. Rozenblatt-Rosen O, Hughes CM, Nannepaga SJ, Shanmugam KS, Copeland TD et al (2005) The parafibromin tumor suppressor protein is part of a human Paf1 complex. Mol Cell Biol 25:612-620

38. Yart A, Gstaiger M, Wirbelauer C, Pecnik M, Anastasiou D et al (2005) The HRPT2 tumor suppressor gene product parafibromin associates with human PAF1 and RNA polymerase II. Mol Cell Biol 25:5052-5060

39. Shattuck TM, Välimäki S, Obara T, Gaz RD, Clark $\mathrm{OH}$ et al (2003) Somatic and germ-line mutations of the HRPT2 gene in sporadic parathyroid carcinoma. N Engl J Med 349:1722-1729

40. Tan MH, Morrison C, Wang P, Yang X, Haven CJ et al (2004) Loss of parafibromin immunoreactivity is a distinguishing feature of parathyroid carcinoma. Clin Cancer Res 10:6629-6637

41. Krebs LJ, Shattuck TM, Arnold A (2005) HRPT2 mutational analysis of typical sporadic parathyroid adenomas. J Clin Endocrinol Metab 90:5015-5017

42. Weinstein LS, Simonds WF (2003) HRPT2, a marker of parathyroid cancer. N Engl J Med 349:1691-1692

43. Haid SP, Method HL, Beal JM (1967) Parathyroid cysts. Arch Surg 94:421-426

44. Cappelli C, Gandossi E, Pirola I, De Martino E, Delbarba A, Maurizio C (2007) Parathyroid cyst: often mistaken for a thyroid cyst. World J Surg 31:2269

45. Gough IR (1999) Parathyroid cysts. Aust N Z J Surg 69:404-406

46. Kato H, Kanematsu M, Kiryu T, Iwata H, Shirahashi $\mathrm{K}$ et al (2008) Nonfunctional mediastinal parathyroid cyst: imaging findings in two cases. Clin Imaging 32:310-313

47. Layfield LJ (1991) Fine needle aspiration cytology of cystic parathyroid lesions. A cytomorphologic overlap with cystic lesions of the thyroid. Acta Cytol 35:447-450

48. Ihm PS, Dray T, Sofferman RA, Nathan M, Hardin NJ (2001) Parathyroid cysts: diagnosis and management. Laryngoscope 111:1576-1578

49. Rangnekar N, Bailer WJ, Ghani A, Carbonell FA, Nowak M (1996) Parathyroid cysts. Report of four cases and review of the literature. Int Surg 81:412-414 
50. Pacini F, Antonelli A, Lari R, Gasperini L, Baschieri A et al (1985) Unsuspected parathyroid cysts diagnosed by measurement of thyroglobulin and parathyroid hormone concentrations in fluid aspirates. Ann Intern Med 102:793-794

51. Lerud KS, Tabbara SO, DelVecchio DM, Frost AR (1996) Cytomorphology of cystic parathyroid lesions: report of four cases evaluated preoperatively by fine-needle aspiration. Diagn Cytopathol 15:306-311

52. Prinz RA, Peters JR, Kane JM, Wood J (1990) Needle aspiration of non-functioning parathyroid cysts. Am Surg 56:420-422

53. Locchi F, Cavalli T, Giudici F, Brandi ML, Tonelli F (2014) Intraoperative PTH monitoring: a new approach based on the identification of the "true" time origin of the decay curve. Endocr J 61:239-247

54. Moyes VJ, Monson JP, Chew SL, Akker SA (2010) Clinical use of cinacalcet in MEN1 hyperparathyroidism. Int $\mathrm{J}$ Endocr 2010:906163
55. Falchetti A, Cilotti A, Vaggelli L, Masi L, Amedei A et al (2008) A patient with MEN1-associated hyperparathyroidism, responsive to cinacalcet. Nat Clin Pract Endocrinol 4:351-357

56. Cetani F, Saponaro F, Banti C, Cianferotti L, Vignali E et al (2011) Cinacalcet efficacy in patients with moderately severe primary hyperparathyroidism according to the European Medicine Agency prescription labeling. J Endocr Invest 35:655-660

57. Cozzolino M, Mazzaferro S, Messa P (2011) New insights into the role of calcium-sensing receptor activation. J Nephrol 24(Suppl 18):S38-S41

58. Sanchez A, Carretto H (1993) Treatment of a non-functioning parathyroid cyst with tetracycline injection. Head Neck 15:263-265

59. Akel M, Salti I, Azar ST (1999) Successful treatment of parathyroid cyst using ethanol sclerotherapy. Am J Med Sci $317: 50-52$ 